\title{
Wayang Bèbèr Damarwulan
}

\author{
Mahmudi \\ Jurusan Pedalangan Fakultas Seni Pertunjukan Institut Seni Indonesia Yogyakarta \\ Email: mahmudi.sinobi@gmail.com
}

\begin{abstract}
This "Wayang Bèbèr Damarwulan" work is an interpretation of wayang bèbèr based on the creator's experience in studying arts. This work is a wayang Bèbèr artwork using traditional picture language (two dimension theory) and shape transformation theory. Both of these theories are used to combine the art of "kethoprak" with the story of Damarwulan into Wayang Bèbèr which then performed as a new version of wayang Bèbèr. By combining kethoprak into wayang Bèbèr, it is expected to be a new attractive and interesting wayang Bèbèr performance for the society.
\end{abstract}

Keywords: wayang bèbèr; interpretation; two dimension theory; transformation

\begin{abstract}
Abstrak
Karya Wayang Bèbèr Damarwulan adalah suatu bentuk interpretasi baru dari wayang bèbèr. Interpretasi baru ini lahir dari pengalaman yang diperoleh perancang selama menekuni dunia seni, baik seni lukis maupun seni pedalangan. Karya Wayang Bèbèr Damarwulan ini merupakan penggarapan wayang bèbèr berdasarkan teori bahasa rupa tradisional/RWD (teori ruang waktu datar) dan teori alih wahana. Kedua teori tersebut digunakan sebagai kerangka berpikir dalam merancang Wayang Bèbèr Damarwulan yang merupakan sebuah karya wayang bèbèr versi baru perpaduan antara kethoprak cerita Damarwulan dengan wayang bèbèr. Karya ini diharapkan dapat membuat pertunjukan wayang bèbèr semakin menarik dan diminati masyarakat.
\end{abstract}

Kata kunci: wayang bèbèr; interpretasi; RWD; alih wahana

\section{Pendahuluan}

Wayang bèbèr adalah salah satu jenis wayang yang memiliki keunikan tersendiri. Wayang ini berbeda dengan wayang-wayang lainya, yang kebanyakan dipentaskan dengan menggunakan media yang dapat digerakkan dan dimainkan secara dinamis. Wayang bèbèr berwujud lukisan pada kertas segi panjang dengan ukuran kurang lebih 300 $\mathrm{cm}$ dan lebar $50 \mathrm{~cm}$. Disebut wayang bèbèr karena dipergelarkan dengan cara dibentang atau digelar (Sayid, 1980: 6). Kata bèbèr berarti membuka, membentangkan atau menguraikan (KBBI, 1998:
104). Oleh karena itu wayang bèbèr adalah lukisan yang dapat digulung serta dibentangkan seperti sebuah rol film. Pada umumnya, gulungan wayang bèbèr hanya berisikan sebuah penggalan adegan yang berurutan. Dengan demikian satu lakon terdiri dari bèbèrapa gulungan. Pada kedua ujung gulungan wayang bèbèr dipasang kayu sebagai pengikat dan sekaligus alat penggulung. Dalam pertunjukannya, setelah dibentangkan, kedua kayu pada masing-masing ujung ditancapkan di atas panggung. Biasanya panggung tersebut adalah peti tempat menyimpan wayang bèbèr itu sendiri. Bentuk peti wayang bèbèr jika dilihat mirip 
dengan peti mati Cina, yakni berbentuk balok dengan tutup melengkung setengah lingkaran dan mempunyai empat kaki. Pada bagian ujung kanan dan kiri atas peti terdapat lubang yang digunakan untuk menancapkan batang kayu pada ujung wayang bèbèr agar wayang bèbèr bisa berdiri dan terbentang di atasnya.

Tugas seorang dalang wayang bèbèr adalah menarasikan dan mendeskripsikan cerita yang terdapat dalam gambar yang dibentangkan. Pertunjukan wayang bèbèr juga menggunakan gamelan sebagai ilustrasi. Setelah dalang selesai menceritakan adegan, lukisan tersebut digulung, kemudian lukisan untuk adegan berikutnya dibentangkan, dan dalang menceritakan gambar tersebut; demikian seterusnya hingga gulungan terakhir. Dengan demikian sang dalang telah menyelesaikan pergelaran satu lakon. Keahlian sang dalang dalam menceritakan gambar merupakan sebuah tuntutan sehingga penonton dapat menikmati alur cerita yang dipergelarkan dari keseluruhan gulungan.

Berdasarkan sejarahnya, wayang bèbèr sudah ada sejak zaman Majapahit.Wayang ini merupakan salah satu pertunjukan yang populer di zaman itu. Pada masa itu, wayang bèbèr berasal dari Ponorogo Jawa Timur, yang dibuat di atas kertas, berupa gambar hitam-putih, belum diberi warna atau belum disungging, dengan mengambil lakon dari cerita Mahabarata ataupun Ramayana. Wayang bèbèr mulai disungging pada masa akhir Majapahit sehingga semakin tampak indah. Selain dari aspek bentuknya, wayang bèbèr juga mengalami perkembangan dalam aspek ceritanya. Wayang bèbèr semula berupa gambar manusia realis, kemudian mengalami stilisasi mirip dengan wayang kulit. Cerita wayang bèbèr yang semula melakonkan cerita Mahabarata dan Ramayana, kemudian mulai mengambil cerita Panji dari Jenggala dan lakon Jaka Karèbèt. Perkembangan wayang bèbèr terus berlangsung sampai dengan jaman kerajaan Demak. Adapun lakon wayang bèbèr pada jaman Demak, kebanyakan diambil dari cerita Panji atau Gedhog. Rupa-rupanya hal ini ada hubungannya dengan dibuatnya wayang bèbèr cerita Gedhog oleh Sunan Bonang untuk menggantikan cerita wayang purwa (Sayid, 1980: 6-10). Selain itu juga disebabkan oleh sangat populernya cerita Panji di Nusantara pada saat itu, terutama di daerah Jawa. Cerita Panji ini bahkan tersebar sampai ke Malaysia, Thailand, dan Kamboja (Holt, 1967: 419). Dalam perjalanan selanjutnya, wayang bèbèr mengalami kemunduran karena kalah populer dengan wayang kulit purwa. Popularitas wayang kulit purwa juga menggeser fungsi wayang bèbèr. Wayang Bèbèr yang semula digunakan sebagai media ruwatan, akhirnya tergantikan oleh wayang kulit. Bahkan pada tahun 1630, Raja Mataram melarang penggunaan wayang bèbèr sebagai media ruwatan (Brandon, 2003: 66).

Ada dua buah lakon wayang bèbèr peninggalan zaman dahulu yang masih dapat ditemukan hingga saat ini, yaitu wayang bèbèr lakon Jaka Kembang Kuning di desa Karang Talun, kecamatan Gedompol, kabupaten Pacitan Jawa Timur dan wayang bèbèr lakon Remeng Mangunjaya di dusun Gelaran, kelurahan Bejiharjo, kecamatan Karangmojo, kabupaten Gunung Kidul Yogyakarta. Kedua lakon tersebut merupakan bagian dari cerita Panji. Meskipun sama-sama wayang bèbèr dengan lakon Panji namun keduanya memiliki gaya yang berbeda, baik dari segi lukisan maupun penyajiannya. Wayang bèbèr Joko Kembang Kuning memiliki corak lukisan yang rumit penuh ornamen, penggambaran tokoh dalam setiap adegan rata-rata bersifat statis, sedangkan wayang bèbèr Remeng Mangunjaya memiliki corak lukis yang sederhana, penggambaran adegan rata- rata bersifat dinamis. Wayang bèbèr lakon Joko Kembang Kuning dipentaskan dengan format seperti wayang kulit yang ditonton dari belakang kelir, sedang lakon Remeng Mangunjaya seperti format wayang kulit ditonton dari depan kelir. Tahun pembuatan kedua wayang bèbèr tersebut juga berbeda, wayang bèbèr lakon Remeng Mangunjaya selesai dibuat pada masa pemerintahan Sunan Paku Buwono II (1660) sementara wayang bèbèr lakon Joko Kembang Kuning pada masa Sunan Mangkurat II (1614) (Sayid, 1980: 6-10). Dengan demikian dapat diperkirakan bahwa usia kedua wayang bèbèr tersebut sudah mencapai sekitar 350 dan 400 tahun.

Dewasa ini, pertunjukan wayang bèbèr hanya dapat disaksikan pada saat diadakan festival atau pun ritual. Oleh masyarakat pemiliknya, wayang bèbèr dianggap sebagai wayang yang sakral, yang tidak boleh dibuka pada setiap saat, dan tidak setiap orang boleh mempelajarinya. Sebagai wayang 
yang sakral, jika ingin membukanya di luar waktu yang seharusnya, harus disertai dengan syarat sajen dan ubarampe among-among yang lengkap. Syarat tersebut tentunya menjadi terasa berat karena dalam pembuatan among-among dan sajen ditafsirkan oleh pemilik menghabiskan biaya sekitar Rp. 700.000,(Wawancara dengan Ibu Rubiyem, 2011). Bagi kalangan mayarakat biasa di daerah Gunung Kidul, besaran biaya tersebut relatif mahal sehingga ada keengganan membuka, melihat, dan mempelajari wayang tersebut. Hal demikian mengakibatkan proses regenerasi dalang dan pewarisan ilmu dalang wayang bèbèr tidak dapat berjalan dengan baik.

Faktor penyebab kemunduran wayang bèbèr disebutkan oleh Suharyono (2005: 67-74) dalam bukunya yang berjudul Wayang Bèbèr Wonosari sebagai berikut: (1)Pertunjukannya membosankan karena dalang menceritakan gambar dengan katakata yang monoton; (2) Kurangnya ragam lakon; (3) Cerita Panji merupakan cerita siklus yang monoton; (4) Pertunjukan wayang bèbèr hanyalah sebagai sarana ritual dan peringatan saja; (5) Pertunjukan wayang bèbèr sulit untuk dikembangkan, hanya dari segi seni rupa saja yang bisa dikembangkan; (6) Adanya larangan menggunakan wayang bèbèr untuk keperluan ritual di dalam kerajaan pada zaman Mataram.

Selain penyebab kemunduran wayang bèbèr seperti disebutkan oleh Suharyono (2005: 67-74) tersebut yang perlu diperhatikan adalah kondisi kedua wayang bèbèr yang sudah semakin rapuh, terutama wayang bèbèr lakon Joko Kembang Kuning. Banyak bagian dari wayang bèbèr lakon Joko Kembang Kuning yang ditambal dengan kertas payung, sehingga sudah tidak layak lagi untuk dipentaskan karena sangat beresiko. Selain kondisi wayang yang memprihatinkan, pertunjukan wayang bèbèr pun tidak populer seperti wayang kulit purwa. Dalang wayang bèbèr yang ada sekarang dan sudah bèbèrapa kali pentas adalah Ki Slamet Haryadi. Berdasarkan bèbèrapa pementasan yang dilakukan, perancang berhasil mendapat rekaman utuh pada tanggal 23 Mei 2009, di Pendapa Jurusan Pedalangan dalam acara Dies Natalis ISI Yogyakarta XXV. Ki Slamet Haryadi bukanlah keturunan dalang wayang bèbèr. Beliau adalah dalang wayang kulit purwa yang memberanikan diri mendalang wayang bèbèr karena dalang wayang bèbèr sudah pikun dan tidak mampu lagi mendalang. Oleh karena itu, dalam penyajiannya, Ki Slamet Haryadi terlihat banyak terpengaruh pementasan wayang kulit purwa.

Berdasarkan dinamika perkembangan wayang bèbèr seperti telah disebutkan di atas, menimbulkan kegelisahan dalam diri perancang. Dewasa ini jika diperhatikan wayang bèbèr justru banyak dikembangkan oleh para perupa berupa lukisan kaca, lukisan dinding, mural, komik, dan dikembangkan oleh para sineas menjadi sebuah film animasi, dan lain sebagainya. Hasrat untuk berpartisipasi dan melestarikan wayang bèbèr begitu menggebu dalam diri perancang.

Perancang berasumsi bahwa wayang bèbèr akan kehilangan jati diri dan beralih fungsi menjadi benda yang sifatnya monumental jika tidak ada upaya revitalisasi dalam bentuk pertunjukan. Padahal wayang bèbèr bukanlah lukisan biasa, melainkan sebuah sastra visual. Lukisan wayang bèbèr merupakan sebuah karya yang dibuat untuk menyampaikan sebuah cerita (Tabrani, 2005: 141164).

Pemahaman tentang sejarah perkembangan wayang bèbèr, keprihatinan dan kegelisahan serta asumsi perancang yang telah disampaikan di atas mendorong dirancangnya sebuah karya wayang bèbèr baru dan kemudian mementaskannya. Karya wayang bèbèr baru ini merupakan perpaduan pertunjukan wayang bèbèr dan pertunjukan kethoprak. Ide untuk memadukan dua bentuk kesenian tersebut muncul ketika perancang mendengarkan rekaman kethoprak Sapta Mandala berjudul Damarwulan Ménak Jingga produsi PT Bintang Fajar (2011). Pada saat itu, perancang merasakan ada sesuatu yang menarik. Perancang bisa berimajinasi tinggi dengan mendengarkan rekaman tersebut. Penarasian dengan bahasa sederhana, realistis, dan fleksibel, membuat kethoprak mudah dipahami. Berawal dari hal itu mucul ide perancang untuk mengalihwahanakan pertunjukan kethoprak lakon Damarwulan Ménak Jingga tersebut ke dalam karya wayang bèbèr.

\section{Konsep Ruang Waktu Datar dan Konsep Alih Wahana}

Primadi Tabrani (2005) mengatakan bahwa struktur seni rupa, pada hakikatnya dapat digolongkan menjadi dua macam, yaitu seni 
rupa Ruang Waktu Datar (RWD) dan Naturalis PerspektifMoment Opname (NPM). Ciri-ciri RWD yaitu gambar yang memiliki aneka tampak, baik arah, waktu, maupun jarak. Imaji yang dihasilkan berupa sekuen yang terdiri dari bèbèrapa adegan, gambar bergerak dalam ruang dan waktu sehingga imaji mampu bercerita. RWD pada umumnya digunakan dalam seni rupa tradisi. Ciri-ciri NPM yaitu gambar memiliki satu arah, satu jarak, satu waktu; imaji yang dihasilkan adalah berupa gambar mati (still picture). NPM pada umumnya digunakan dalam seni rupa modern.

Sistem RWD mampu memaparkan cerita yang panjang lebar hanya dengan gambar yang sedikit karena ada bèbèrapa adegan yang dapat dipenjarakan dalam satu frame tanpa terikat ruang dan waktu.

Dijelaskan oleh Tabrani (2005) bahwa struktur seni rupa tradisional, termasuk pula wayang bèbèr, menggunakan sistem RuangWaktu Datar (RWD). Dengan sistem ruang waktu datar, sebuah gulungan wayang bèbèr sangat memungkinkan untuk diceritakan dari berbagai urutan peristiwa.

Sapardi Djoko Damono (2012: 3-4) mengatakan bahwa setiap wahana yang dialihkan ke dalam wahana yang lain akan mengalami perubahan sesuai dengan lingkungan wahana yang baru.

Berdasarkan pandangan di atas, dapat dikatakan bahwa wayang bèbèr menggunakan struktur RWD karena ia merupakan seni rupa tradisi. Sebagai karya seni rupa tradisi lukisan dalam wayang bèbèr bersifat sangat imajinatif, atau bersifat membangun imajinasi orang yang melihatnya. Sistem RWD mampu memaparkan cerita yang panjang lebar hanya dengan gambar yang sedikit karena ada bèbèrapa adegan yang dapat dipenjarakan dalam satu frame tanpa terikat ruang dan waktu. Mengingat bahwa lakon Damarwulan adalah cerita yang panjang, maka untuk menuangkan ke dalam bentuk wayang bèbèr, digunakan struktur RWD agar gambarnya efektif dan menarik.

Cerita Damarwulan dalam karya wayang bèbèr ini bersumber dari lakon kethoprak, maka dilakukan alih wahana ketika dijadikan wayang bèbèr. Dalam peralihan wahana tersebut ada bèbèrapa idiom-idiom kethoprak yang tetap dipertahankan, di antaranya adalah pengadegan, gaya penarasian, bahasa, dan intonasi dialog sehingga menjadi format wayang bèbèr yang baru.

\section{Proses Perancangan Wayang Bèbèr Damarwulan}

Langkah-langkah yang dilakukan, agar mencapai hasil maksimal dalam pembuatan karya ini, diantaranya seperti berikut:

1. Pengumpulan data.

Ada bèbèrapa jenis data yang dikumpulkan, yaitu data pertunjukan, gambar, dan wawancara. Data pertunjukan diperoleh melalui perekaman pertunjukan wayang bèbèr. Data gambar diperoleh melalui pemotretan wayang bèbèr. Sampai saat ini wayang bèbèr hanya boleh dibuka saat pertunjukan, maka dari itu pemotretan dilakukan pada saat pertunjukan berlangsung. Data wawancara diperoleh melalui wawancara dengan para dalang wayang bèbèr dan pewaris wayang bèbèr.

Agar karya ini tidak melenceng jauh dari konsep wayang bèbèr, maka diperlukan pemahaman tentang sejarah singkat wayang bèbèr, sinopsis cerita lakon wayang bèbèr, foto lengkap, sekaligus jalan cerita lakon wayang bèbèr Joko Kembang Kuning maupun Remeng Mangunjaya (Dirjen Kebudayaan, 1983-1984; Sayid, 1980). Penjelasan dalam buku tersebut digunakan sebagai acuan dalam pembuatan bentuk figur-figur pada lukisan wayang bèbèr.

Data mengenai pertunjukan wayang bèbèr, perancang dapatkan saat pementasan dalam acara bersih desa yang diadakan oleh masyarakat desa Gelaran, kelurahan Bejiharjo, kabupaten Gunung Kidul Yogyakarta pada tanggal 9 Oktober 2010, dengan dalang Ki Karmanto dari Gelaran II, Bejiharjo, Gunung Kidul. Seperti halnya Ki Slamet Haryadi, Ki Karmanto tidak membaca gambar namun membawakan penceritaan sesuai pengetahuan beliau, dan kadangkadang antara gambar yang dibuka dengan penceritaan tidak cocok.

2. Pendalaman materi.

Perancang menganalisis gambar-gambar wayang bèbèr dan wayang klithik untuk membuat figur-figur dalam wayang bèbèr lakon Damarwulan. Selain itu perancang juga membaca literatur tentang wayang bèbèr dan materi lain yang mendukung pembuatan serta pemanggungan Wayang Bèbèr Damarwulan.

3. Penyusunan naskah dan pembuatan wayang bèbèr Damarwulan. 
Setelah melakukan pendalaman materi kemudian perancang menyusun naskah wayang bèbèr lakon Damarwulan. Naskah yang digunakan diadaptasi dari dialog-dialog yang terdapat dalam kethoprak Sapta Mandala dengan judul Damarwulan Ménak Jingga. Dialog-dialog tersebut kemudian ditranskrip dan diolah menjadi sebuah naskah yang baru dengan tidak mengubah alur dramatiknya.

Wayang bèbèr ini dibuat menjadi tiga gulungan, masing-masing gulungan berisi empat sekuen. Sebelum memulai proses membuat wayang bèbèr perancang memilah-milah adegan terlebih dahulu menjadi 12 sekuen, dan selanjutnya dilakukan proses pembuatan wayang bèbèr. Bahan yang digunakan dalam pembuatan wayang bèbèr lakon Damarwulan ini adalah akrilik di atas kain kanvas.

4. Latihan.

Setelah proses pembuatan naskah dan wayang bèbèr selesai, proses selanjutnya adalah latihan. Adapun proses latihannya adalah sebagai berikut: (1) Pendalaman naskah dan wayang bèbèr; (2) Eksplorasi retorika dalam menarasikan wayang bèbèr; (3) Latihan bersama dengan iringan; (4) Gladi bersih; (5) Penyajian karya.

Setelah semua proses dijalani maka tahap yang terahir adalah pementasan wayang bèbèr dengan lakon Damarwulan yang akan disajikan dengan durasi 90 menit. Dalam waktu satu setengah jam tersebut perancang akan menarasikan cerita dengan dialog, kandha, dan bèbèrapa tembang guna membangun suasana yang terjadi dalam gambar.

\section{Bentuk dan Pementasan Wayang Bèbèr Damarwulan}

Berikut adalah pemaparan proses perancangan Wayang Bèbèr Damarwulan. Pemaparan ini meliputi proses alih wahana dari kethoprak ke dalam wayang bèbèr, dan proses pembuatan wayang bèbèr.

a. Dari Lakon Damarwulan Ménak Jingga Ke Wayang Bèbèr Damarwulan

Pada dasarnya, cerita Damarwulan merupakan sebuah dongeng yang sudah tidak asing bagi sebagian besar masyarakat Jawa. Cerita Damarwulan mengisahkan seorang pemuda yang menjadi pahlawan Kerajaan
Majapahit dalam menumpas pemberontakan Adipati Ménak Jingga dari Kadipaten Blambangan. Pada umumnya, masyarakat mengenal cerita Damarwulan ini melalui tradisi lisan secara turun-temurun. Namun demikian, cerita Damarwulan juga dapat dijumpai dalam bentuk teks, prosa, tembang, dan cerita dongeng, baik itu dalam bahasa Jawa maupun bahasa Indonesia. Cerita Damarwulan juga menjadi populer di masyarakat sebagai lakon pertunjukan, seperti: pementasan kethoprak, sandiwara, wayang klithik, dan langendriyan.

Pertunjukan kethoprak sering mementaskan Lakon Damarwulan karena lakon ini sangat digemari masyarakat. Sapardi Djoko Damono (2012: 39-46) mengatakan bahwa kethoprak merupakan salah satu kesenian teater tradisi yang bertahan sejak abad ke XIX sampai saat ini karena memiliki kelebihan tersendiri. Kelebihan itu di antaranya adalah: (1) kethoprak merupakan kesenian yang fleksibel, mudah beradaptasi dengan lingkungan, (2) kethoprak disajikan dengan bahasa yang sederhana, ekspresi yang realistis serta fleksibel, (3) kethoprak merupakan kesenian yang terbuka untuk jenis lakon apapun, baik secara lisan maupun tulis.

Salah satu paguyuban kethoprak yang pernah mementaskan Lakon Damarwulan dan didokumentasikan menjadi pita kaset adalah kethoprak Sapta Mandala. Lakon ini direkam oleh studio rekaman PT Bintang Fajar Record ke dalam empat kaset. Lakon Damarwulan versi kethoprak Sapta Mandala diawali dengan cerita Patih Angkat Buta dan Ongkot Buta datang ke Keraton Majapahit memberikan surat lamaran dari Adipati Ménak Jingga kepada Ratu Kencana Wungu. Meskipun lamaran tersebut ditolak oleh raja Majapahit, namun kedua utusan tersebut tetap memaksa. Melihat gelagat yang tidak menyenangkan, putra Patih Logendèr, yaitu Layang Séta dan Layang Kumitir pun marah dan menantang bertarung kedua utusan tersebut. Berkat tipu daya Patih Logendèr, kedua utusan tersebut dapat diusir dari Majapahit, dan kembali ke Blambangan.

Setelah kejadian tersebut Sang Ratu Kencana Wungu bersamadi. Dewa memberi petunjuk agar Ratu Kencana Wungu mengangkat seorang abdi di Kepatihan yang bernama 
Damarwulan menjadi senapati untuk mengalahkan Ménak Jingga. Damarwulan menerima tugas tersebut, dan pergi ke Blambangan. Berkat siasatnya, Damarwulan berhasil mengalahkan dan memenggal kepala Adipati Ménak Jingga. Kepala itu dibawa ke Majapahit sebagai bukti. Ketika di tengah jalan, Damarwulan dihadang oleh Layang Séta dan Layang Kumitir. Kepala Ménak Jingga dirampas, Damarwulan dibunuh. Atas pertolongan Begawan Tunggul Manik, Damarwulan bisa hidup kembali. Ia segera ke Majapahit dengan membawa bukti lain berupa putri selir Ménak Jingga. Sesampainya di Majapahit, terjadilah perdebatan mengenai siapa yang sesungguhnya mengalahkan Adipati Ménak Jingga. Untuk membuktikan kebenarannya, Damarwulan diadu perang tanding melawan Layang Séta dan Layang Kumitir. Layang Séta dan Layang Kumitir dapat dikalahkan. Damarwulan menjadi suami Ratu Kencana Wungu dan diangkat menjadi Raja Majapahit, bergelar Prabu Brawijaya. Patih Logendèr beserta Layang Séta dan Layang Kumitir pergi meninggalkan Majapahit.

Saudara seperguruan Adipati Ménak Jingga yang bernama Ménak Sumpena tidak terima atas kematian saudaranya. Atas hasutan Patih Logendèr serta kedua putranya, Ménak Sumpena menyerang Damarwulan. Dengan tipu dayanya, Ménak Sumpena membunuh Damarwulan di tengah hutan, dan berniat menguasai Majapahit. Lagi-lagi, Damarwulan mendapat pertolongan dari Begawan Tunggul Manik, sehingga sembuh dan kembali ke Majapahit. Akhirnya Ménak Sumpena dapat dikalahkan Damarwulan, dan Majapahit kembali aman.

Cerita di atas merupakan sinopsis utuh dari lakon Damarwulan Ménak Jingga dalam pertunjukan Kethoprak Sapta Mandala. Selanjutnya, pertunjukan kethoprak tersebut dialihwahanakan dalam format pertunjukan wayang bèbèr. Namun demikian, lakon tersebut tidak ditampilkan utuh dalam wayang bèbèr ini, melainkan hanya sampai pada matinya Ménak Jingga yang merupakan klimaks dari cerita tersebut.

b. Proses Pembuatan Wayang Bèbèr Damarwulan

Untuk mencapai hasil yang maksimal maka pembuatan wayang bèbèr ini melalui beberapa tahap.Tahap-tahap tersebut adalah sebagai berikut:

1. Persiapan bahan

Bahan-bahan yang digunakan untuk membuat Wayang Bèbèr Damarwulan meliputi: (1) Kanvas sebagai media untuk melukis wayang bèbèr. Karya ini menggunakan kain kanvas bukan kertas seperti wayang bèbèr yang asli. Perancang memilih menggunakan kanvas karena dinilai lebih kuat dan tidak mudah sobek. Kanvas yang digunakan dalam pembuatan wayang ini berbeda dengan yang digunakan untuk melukis pada umumnya. Kanvas ini lebih tipis karena bertujuan agar lebih mudah untuk digulung dan dibentangkan.

Adapun proses pembuatan kanvas ini seperti berikut: (a) Penyiapan kain yang digunakan dalam pembuatan kanvas wayang bèbèr ini yaitu kain mori putih yang tipis. Kain tersebut merupakan jenis kain primisima yang banyak dijumpai di toko kain. Kain dipotong sesuai ukuran panjang yang diinginkan kemudian dibentangkan menggunakan bingkai kayu. (b) Pembentangan kain di atas bingkai kayu yang telah disediakan menggunakan paku. Kain yang sudah terbentang kemudian permukaannya dilapisi dengan cat yang sudah diproses menjadi pelapis. (c) Melapisi kain dengan campuran lem kayu dan cat tembok warna coklat muda agak kekuningan untuk menghasilkan kanvas yang berwarna coklat kekuningan. Proses melapisi kain dilakukan dengan mengoleskan campuran lem dan cat tembok di atas secara merata pada permukaan kain yang sudah dibentang menggunakan kuas besar (kuas cat tembok). (d) Finishing kanvas, yaitu kain yang sudah diolesi dengan campuran lem dan cat tembok kemudian dijemur hingga kering. Setelah kering, kain tersebut digosok permukaannya menggunakan kertas amplas yang teksturnya agak halus kira-kira berukuran $240 \mathrm{~cm}$. Kain yang sudah halus kemudian dilepas dari bentangan dan dipotong sesuai keinginan. (2) Cat tembok warna putih yang digunakan dalam pembuatan wayang bèbèr ini merek Decolith. Cat tersebut menurut perancang 
disamping lebih murah juga memiliki kualitas yang bagus dengan kapasitas kepekatan yang tidak jauh berbeda dengan cat merek Mowilex yang harganya mahal. (3) Pigmen warna atau sendi digunakan untuk membuat warna-warna yang diinginkan, dengan cara mencampurkannya pada cat tembok warna putih. Warna pigmen terdiri dari tiga warna yaitu merah, kuning, dan biru, yang dapat diolah menjadi bermacammacam warna yang diinginkan dengan cara mencampurkannya. (4) Tinta hitam merk Yamura khusus untuk warna hitam. Adapun alasan tidak menggunakan sendi hitam agar warna yang di hasilkan lebih pekat dan memiliki kapasitas keenceran yang pas. (5) Cat besi digunakan sebagai perekat warna emas. Untuk warna emas perancang menggunakan merek Avian warna kuning agak orange supaya tidak beda jauh dengan warna emas. (6) Plastik Emas atau Grènjèng adalah plastik yang memang khusus digunakan untuk memberi warna emas. Cara penggunaannya yaitu: gambar bidang yang diinginkan berwarna emas terlebih dahulu diblok atau diberi perekat menggunakan cat besi. Setelah cat agak kering, kemudian tempelkan bagian belakang grènjèng ke bidang tersebut dan digosok menggunakan sikat gigi sampai rata, kemudian grènjèng ditarik dengan keras. Dengan demikian warna emas pada grènjèng tertinggal menempel pada bidang yang telah diberi lapisan cat besi tersebut. (7) Air teh digunakan sebagai pelapis kanvas supaya terlihat kusam sehingga terkesan antik. Kesan antik dirasa perlu agar mempunyai nilai artistik tersendiri. (8) Kayu sebagai bahan pembuatan sligi yang digunakan untuk membentangkan wayang bèbèr. Sligi tersebut dipasang dibagian tepi kanan dan kiri gulungan wayang bèbèr.

2. Persiapan alat

Alat-alat yang digunakan dalam pembuatan Wayang Bèbèr Damarwulan ini adalah: (1) Kuas, kuas yang digunakan dalam pembuatan wayang bèbèr ini ada beberapa macam di antaranya adalah kuas cat tembok, kuas lukis besar, kuas sedang, dan kuas kecil. Kuas cat tembok, digunakan untuk melapisi kanvas. Kuas cat air besar ukuran 6 atau 7, digunakan untuk mengecat bagian-bagian yang sifatnya lebar (blok). Kuas cat air sedang ukuran 4 , digunakan untuk mengecat bidang-bidang yang sifatnya agak lebar. Kuas cat air kecil ukuran 2, digunakan pada bidang bidang yang kecil atau rumit. (2) Bekas gelas aqua sebagai pengganti palet, tempat mencampur warna atau wadah mencampur warna. (3) Pena digunakan untuk menegaskan garis pola serta membuat kontur. Biasanya pena menggunakan bolpoint merk Standard ukuran 0,5 dan spidol Snowman permanen ukuran 0,8. (4) Gunting untuk memotong kanvas.

\section{Proses dan Teknik Pembuatan Wayang Bèbèr Damarwulan}

Pembuatan Wayang Bèbèr Damarwulan ini terbagi menjadi empat tahap, yaitu: (1) Menentukan Pembagian Adegan. Langkah awal dalam membuat wayang bèbèr ini adalah dengan menentukan pembagian adegan yang akan dilukis pada masing-masing sekuen. Pembagian adegan ini dilakukan setelah mendengarkan dan mentranskrip pita kaset Lakon Damarwulan Ménak Jingga yang di produksi oleh PT Bintang Fajar Record. Setelah mendapatkan transkripsi, kemudian adegan dipilah-pilahkan untuk menentukan bagian mana saja yang akan divisualkan dalam wujud gambar. (2) Membuat Pola. Setelah menentukan pembagian adegan, langkah selanjutnya membuat pola lukisan pada kanvas. Pola dibuat dengan pensil terlebih dahulu kemudian pola tersebut dipertegas menggunakan bollpoint. Ada beberapa motif yang polanya dibuat menggunakan bantuan mal kertas karbon karena kebutuhan motif yang sama. (3) Mewarnai. Setelah pola selesai, kemudian kanvas yang sudah digambar dilapisi atau diberi air teh sampai rata supaya kanvas nampak kusam. Perancang berasumsi dengan warna kusam pada kanvas mampu menimbulkan efek antik sehingga kelihatan memiliki nilai artistik tersendiri (semu). Pola yang sudah siap kemudian diwarnai dengan teknik sungging yang sederhana. Sunggingan hanya tiga tingkatan gradasi warna dari terang, sedang 
ke gelap. Warna-warna yang digunakan dalam pewarnaan wayang bèbèr ini merupakan hasil kombinasi campuran dari lima warna, yaitu merah, kuning, biru, hitam, dan putih. Setelah selesai pewarnaan, kemudian tahap berikutnya adalah menempelkan warna emas (nggrènjèng). Tahap terahir dalam pewarnaan ini adalah menegaskan kontur pada motif dengan bollpoin hitam untuk memulihkan garis-garis yang tertutup cat.

\section{Wujud Wayang Bèbèr Damarwulan}

Wayang Bèbèr Damarwulan ini terdiri dari tiga gulungan, yang menceritakan perjalanan Damarwulan, dari mengabdi sampai diangkat menjadi Maha Senapati yang mengalahkan Ménak Jingga. Gulungan tersebut rata-rata berukuran panjang kurang lebih $300 \mathrm{~cm}$ dan lebar kurang lebih $50 \mathrm{~cm}$. Ukuran tersebut merupakan ukuran yang tidak jauh beda dari wayang bèbèr Wonosari. Masing-masing gulungan berisi empat sekuen cerita yang berbeda-beda. Adegan pertemuan, berdialog, pertikaian, dan perang. Gambar adegan disebut sekuen, karena dalam setiap frame gambar terdapat lebih dari satu adegan (Tabrani, 2005: 144). Pola demikian digunakan untuk pembagian gambar adegan dalam Wayang Bèbèr Damarwulan ini. Sekuen wayang bèbèr ini, merupakan visualisasi dari transkripsi pertunjukan Kethoprak Sapta Mandala lakon Damarwulan Ménak Jingga yang diambil dari adegan-adegan yang kiranya bisa mewakili alur cerita. Adegan yang sudah dipilih kemudian diwujudkan ke dalam bentuk wayang bèbèr menjadi dua belas sekuen yang terbagi dalam tiga gulungan seperti diuraikan berikut ini:

1. Gulungan pertama.

Gulungan pertama (gambar 1) berupa rangkaian dari empat sekuen Lakon Damarwulan yang berurutan dari sekuen satu sampai empat. Urutan sekuen tersebut dari kanan ke kiri dan masing-masing sekuen dibaca dari kiri ke kanan. Ornamen yang digunakan dalam gulungan ini berupa stilisasi pohon, bangunan, hewan, karang, properti kerajaan, dan matahari. Media lukisan ini adalah kain kanvas dengan panjang $310 \mathrm{~cm}$ dan lebar $57 \mathrm{~cm}$, sementara panjang lukisan $300 \mathrm{~cm}$ serta tinggi lukisan $50 \mathrm{~cm}$.

2. Gulungan kedua.

Gulungan kedua (gambar 2) pada dasarnya hampir sama dengan gulungan pertama yang merupakan kelanjutan Lakon Damarwulan dari gulungan pertama. Gulungan ini berupa

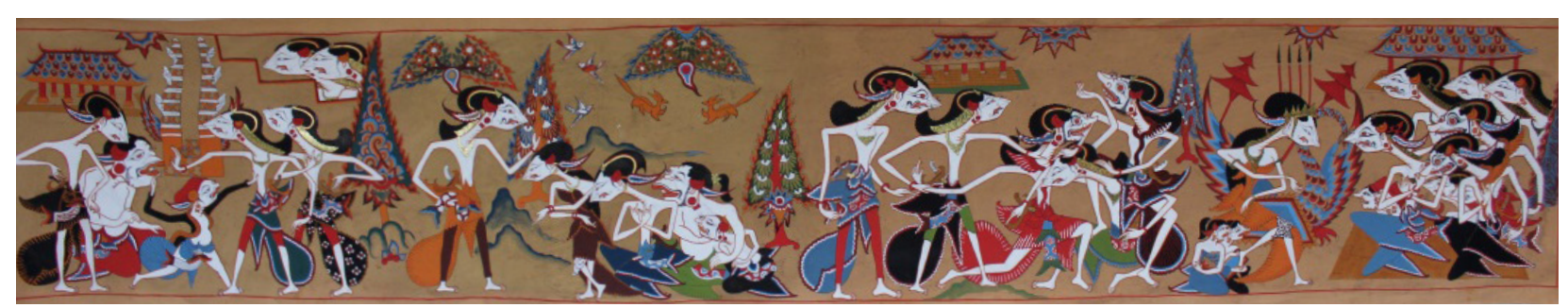

Gambar 1. Gulungan pertama wayang bèbèr karya Mahmudi. (Foto: Elisha, 2013)

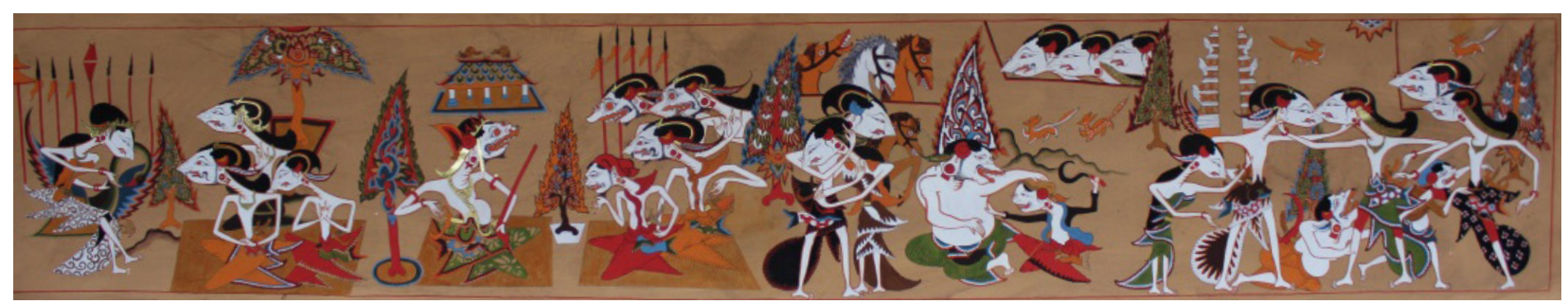

Gambar 2. Gulungan kedua wayang bèbèr karya Mahmudi. (Foto: Elisha, 2013)

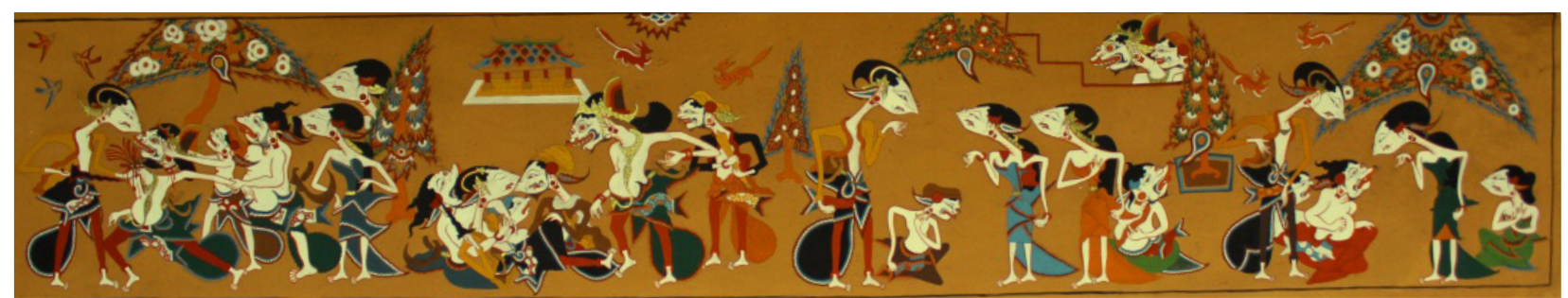

Gambar 3. Gulungan ketiga wayang bèbèr karya Mahmudi. (Foto: Elisha, 2013) 
rangkaian dari sekuen lima sampai delapan. Urutan sekuen tersebut dari kanan ke kiri dan masing-masing sekuen dibaca dari kiri ke kanan. Ornamen yang digunakan dalam gulungan ini berupa stilisasi pohon, bangunan, hewan, karang, properti kerajaan, dan matahari. Media lukisan ini adalah akrilik di atas kain kanvas dengan panjang $314 \mathrm{~cm}$ dan lebar $56 \mathrm{~cm}$, sementara panjang lukisan $303 \mathrm{~cm}$ serta tinggi $50 \mathrm{~cm}$.

3. Gulungan ketiga.

Gulungan ketiga (gambar 3) masih sama dengan gulungan kedua dan pertama merupakan kelanjutan Lakon Damarwulan dari gulungan kedua. Gulungan ketiga ini memuat empat sekuen yaitu sekuen kesembilan sampai kedua belas.Urutan sekuen dari kanan ke kiri dan masing-masing sekuen dibaca dari kiri ke kanan. Ornamen yang digunakan dalam gulungan ini berupa stilisasi pohon, bangunan, hewan, karang, properti kerajaan, dan matahari. Media lukisan ini adalah akrilik di atas kain kanvas dengan panjang $291 \mathrm{~cm}$ dan lebar $56 \mathrm{~cm}$, sementara panjang lukisan $279 \mathrm{~cm}$ serta tinggi $49 \mathrm{~cm}$. Gulungan ini merupakan gulungan yang terakhir dari Wayang Bèbèr Damarwulan.

Ketiga gulungan wayang bèbèr seperti telah dikemukakan di depan merupakan implementasi alur cerita Damarwulan yang diambil dari Kethoprak Sapta Mandala dengan lakon Damarwulan Ménak Jingga. Alur cerita yang digambar dalam ketiga gulungan tersebut terbagi menjadi dua belas sekuen seperti diterangkan berikut ini:

a. Sekuen pertama.

Sekuen pertama (gambar 4) menceritakan tentang pertemuan di Keraton Majapahit.

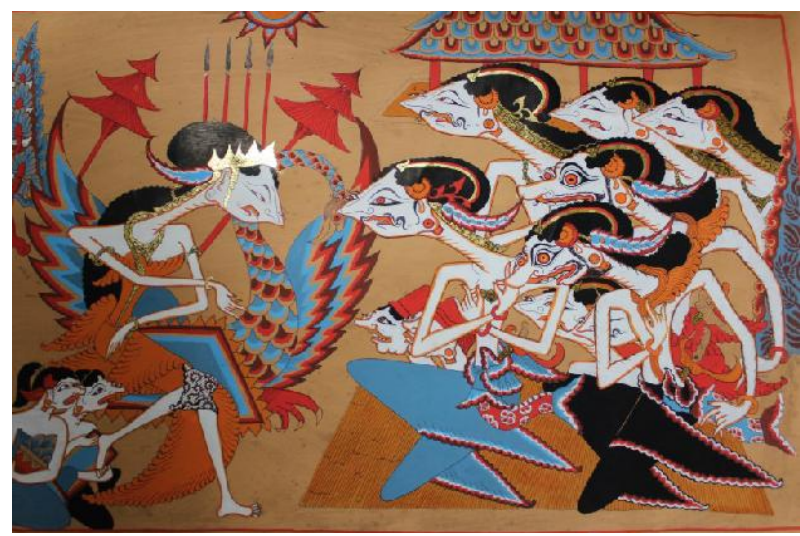

Gambar 4. Sekuen pertama dari gulungan pertama wayang bèbèr karya Mahmudi. (Foto: Elisha, 2013)
Ratu Kencana Wungu dihadap para petinggi kerajaan, seperti: Patih Logendèr, Adipati Lumajang Ménak Koncar, Layang Séta, Layang Kumitir, dan beberapa prajurit. Pertemuan tersebut membahas tentang pencarian jago yang dapat menandingi Ménak Jingga. Dalam pertemuan tersebut belum mendapat keputusan, datanglah dua orang utusan dari Blambangan yang bernama Patih Angkat Buta dan Patih Ongkot Buta. Kedua duta tersebut diutus Ménak Jingga untuk memberikan surat lamaran kepada Ratu Kencana Wungu. Ratu Kencana Wungu sedih sekaligus marah ketika menerima dan membaca surat tersebut kemudian meninggalkan pertemuan. Suasana dalam keraton menjadi ricuh. Kedua duta dari Blambangan tersebut diseret keluar oleh Layang Séta dan Layang Kumitir.

b. Sekuen kedua.

Sekuen kedua (gambar 5) melukiskan peperangan di luar Kerajaan Majapahit antara Layang Séta, Layang Kumitir dengan Patih Angkat Buta dan Ongkot Buta. Peperangan terjadi sangat seru, tak lama kemudian datanglah Patih Logendèr melerai perkelahian mereka. Patih Logendèr menyuruh Angkat Buta dan Ongkot Buta kembali ke Blambangan. Dengan tipu daya Patih Logendèr menjanjikan suatu saat Ratu Kencana Wungu akan memberikan jawaban lamaran Adipati Ménak Jingga. Patih Angkat Buta dan Ongkot Buta pun akhirnya pulang ke Kadipaten Blambangan beserta pasukan yang dibawanya.

c. Sekuen ketiga.

Sekuen ketiga (gambar 6) menceritakan suasana di dalam Kepatihan. Anjasmara putri Patih

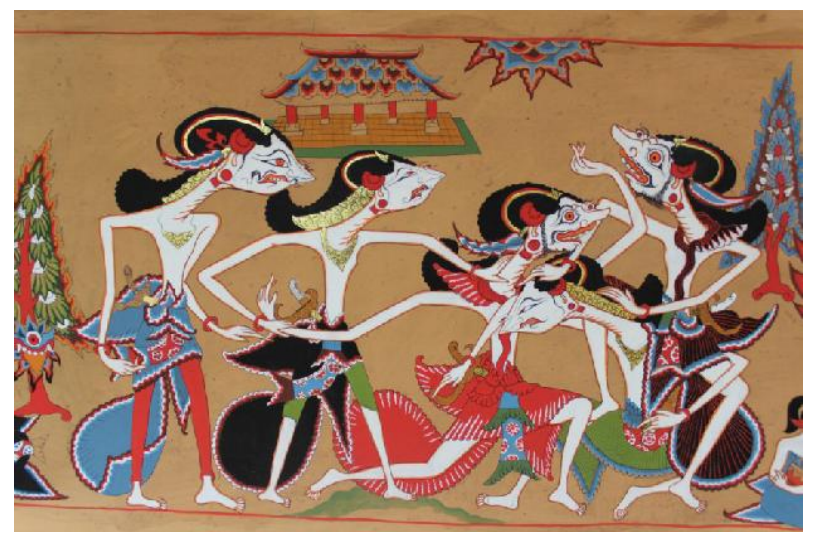

Gambar 5. Sekuen kedua dari gulungan pertama wayang bèbèr karya Mahmudi. (Foto: Elisha, 2013) 
Logendèr sedang bersendau gurau dengan seorang abdinya. Datanglah Patih Logendèr yang baru saja pulang dari pertemuan di keraton Majapahit. Merekapun bersendau gurau bersama. Setelah beberapa lama datanglah Damarwulan beserta abdinya yaitu Sabda Palon dan Naya Genggong. Kedatangan Damarwulan di Kepatihan ingin meminta pekerjaan kepada Patih Logendèr. Damarwulanpun diberi pekerjaan sebagai penjaga pintu gerbang di Kepatihan.

d. Sekuen keempat.

Sekuen keempat (gambar 7) menceritakan tentang keadaan di depan pintu gerbang Kepatihan ketika terjadi cekcok antara rombongan Damarwulan yang sedang bekerja menjaga gerbang Kepatihan dengan Layang Séta dan Layang Kumitir. Percekcokan tersebut menimbulkan emosi pada Layang Séta dan Layang Kumitir hingga mereka marah dan menghajar Damarwulan beserta kedua abdinya.

e. Sekuen kelima.

Sekuen kelima (gambar 8) menceritakan tentang keadaan di depan pintu gerbang Kepatihan.

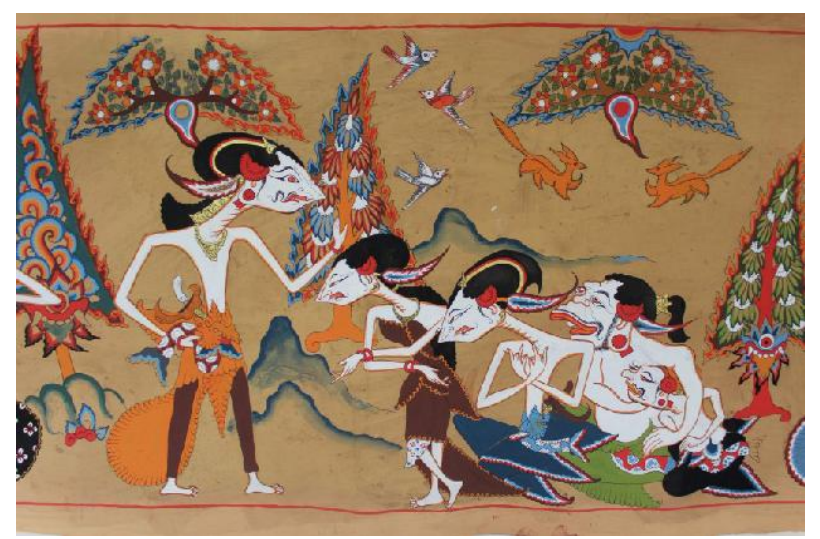

Gambar 6. Sekuen ketiga dari gulungan pertama wayang bèbèr karya Mahmudi. (Foto: Elisha, 2013)

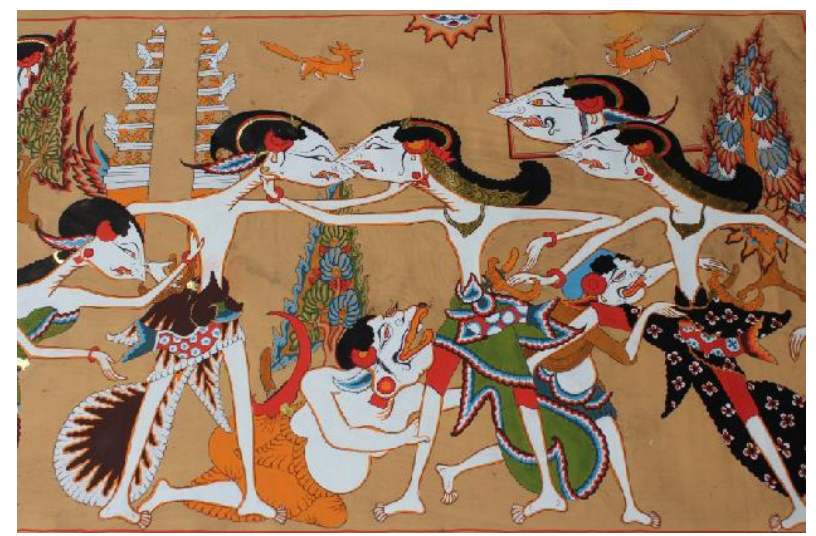

Gambar 8. Sekuen pertama dari gulungan kedua wayang bèbèr karya Mahmudi. (Foto: Elisha, 2013)
Dalam sekuen ini Damarwulan beserta rombongan bertikai dengan Layang Séta dan Layang Kumitir yang hendak masuk ke dalam Kepatihan akan tetapi dihalang-halangi oleh Damarwulan beserta rombongan. Keributan terjadi karena kesalahpahaman antara kedua belah pihak, hingga akhirnya keributan tersebut dilerai oleh Patih Logendèr. Damarwulan dipindahtugaskan menjadi perawat kuda.

f. Sekuen keenam.

Sekuen keenam (gambar 9) melukiskan adegan di kandang kuda (gedogan). Anjasmara menemui Damarwulan dan mengungkapkan cinta kepadanya. Peristiwa tersebut diketahui oleh Patih Logendèr, Layang Séta dan Layang Kumitir. Damarwulan dianggap salah dalam hal ini sehingga ia dipenjara. Anjasmara ikut menjalani hukuman itu. Akhirnya keduanya dipenjara.

g. Sekuen ketujuh.

Sekuen ketujuh (gambar 10) menggambarkan suasana di Kadipaten Blambangan. Prabu Ménak Jingga dihadap oleh Dayun dan Adipati Déwagung Wali Krama. Dalam pertemuan tersebut Prabu Ménak Jingga sedang dimabuk

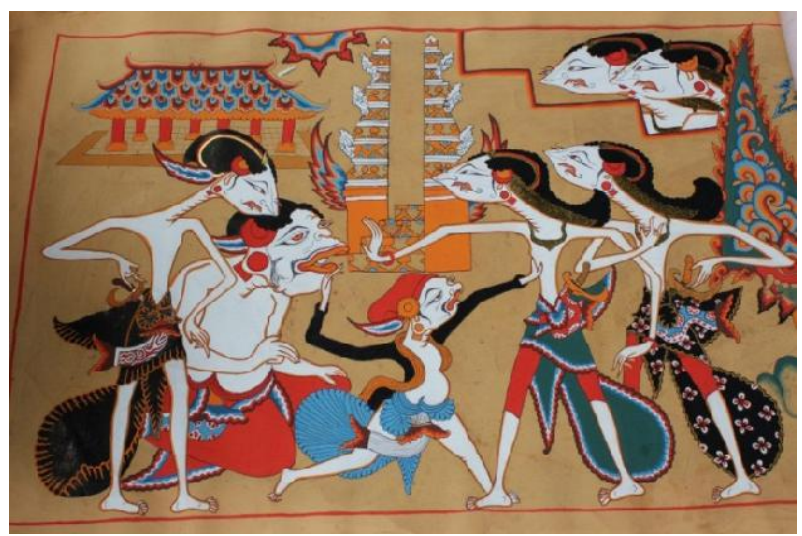

Gambar 7. Sekuen keempat dari gulungan pertama wayang bèbèr karya Mahmudi. (Foto: Elisha, 2013)

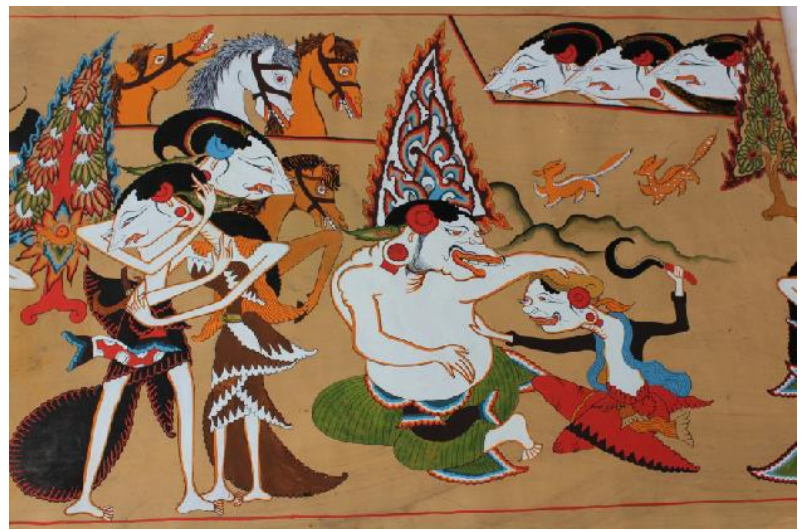

Gambar 9. Sekuen kedua dari gulungan kedua wayang bèbèr karya Mahmudi. (Foto: Elisha, 2013) 
cinta dengan Ratu Kencana Wungu. Ia menunggu Patih Angkat Buta dan Patih Ongkot Buta yang sedang diutus menyampaikan lamarannya kepada Ratu Kencana Wungu. Tidak berapa lama datanglah Patih Angkat Buta dan Patih Ongkot Buta. Kedua duta tersebut membawa kabar bahwa lamarannya belum diterima.

h. Sekuen kedelapan.

Sekuen kedelapan (gambar 11) menceritakan tentang suasana di Keraton Majapahit. Ratu Kencana Wungu dihadap Patih Logendèr dan Adipati Ménak Koncar. Dalam pertemuan tersebut Damarwulan dipilih menjadi senapati untuk melawan Ménak Jingga oleh Ratu Kencana Wungu. Damarwulan dipilih menjadi senapati berdasarkan wangsit dewa yang diperoleh Ratu Kencana Wungu ketika bersamadi.

i. Sekuen kesembilan.

Sekuen kesembilan (gambar 11) menceritakan ketika Damarwulan berpamitan kepada Anjasmara di Kepatihan. Damarwulan dan Anjasmara sempat beradu pendapat tentang kepergian Damarwulan ke Blambangan. Anjasmara tidak mengizinkan Damarwulan pergi melawan

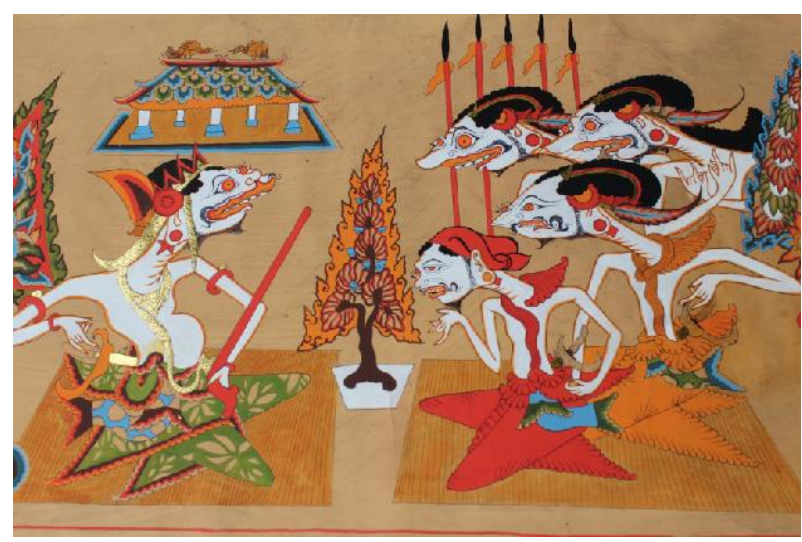

Gambar 10. Sekuen ketiga dari gulungan kedua wayang bèbèr karya Mahmudi. (Foto: Elisha, 2013)

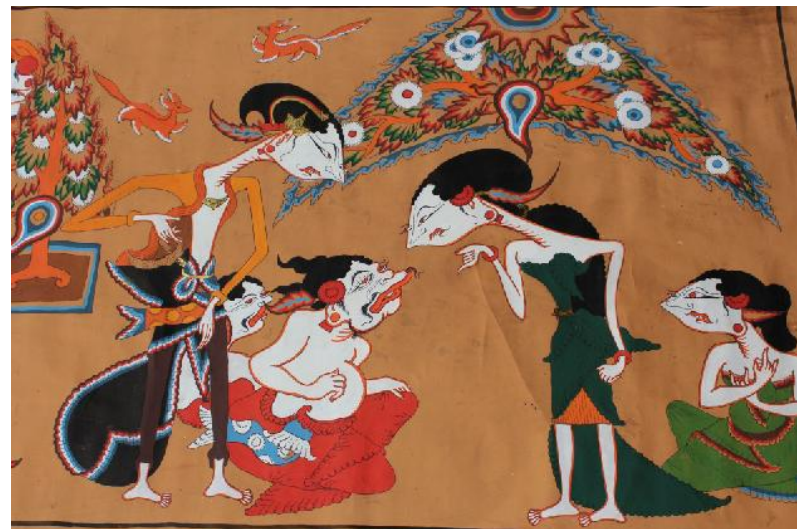

Gambar 12. Sekuen pertama dari gulungan ketiga wayang bèbèr karya Mahmudi. (Foto: Elisha, 2013)
Ménak Jingga, mengingat kekuatan Ménak Jingga yang begitu besar. Dengan berbagai argumentasinya, akhirnya Damarwulan berangkat ke Blambangan meninggalkan Anjasmara.

j. Sekuen kesepuluh.

Sekuen kesepuluh (gambar 12) menceritakan Damarwulan yang berada di Tamansari Keputren Blambangan. Damarwulan beserta kedua abdinya menemui dua wanita yang ditawan oleh Ménak Jingga yang bernama Wahita dan Puyengan. Kedua wanita yang ditawan itu hendak dijadikan selir oleh Ménak Jingga. Damarwulan hendak menolong kedua wanita itu dengan tujuan mencari informasi tentang kelemahan Ménak Jingga.Tidak berapa lama datanglah Ménak Jingga beserta Dayun di Keputren Blambangan. Ménak Jingga marah besar melihat ada laki-laki masuk dan mendekati kedua wanita calon selirnya.

k. Sekuen kesebelas.

Sekuen kesebelas (gambar 13) menceritakan tentang perang Damarwulan melawan Ménak Jingga. Damarwulan tidak mampu menandingi kekuatan Ménak Jingga sehingga ia kalah dan

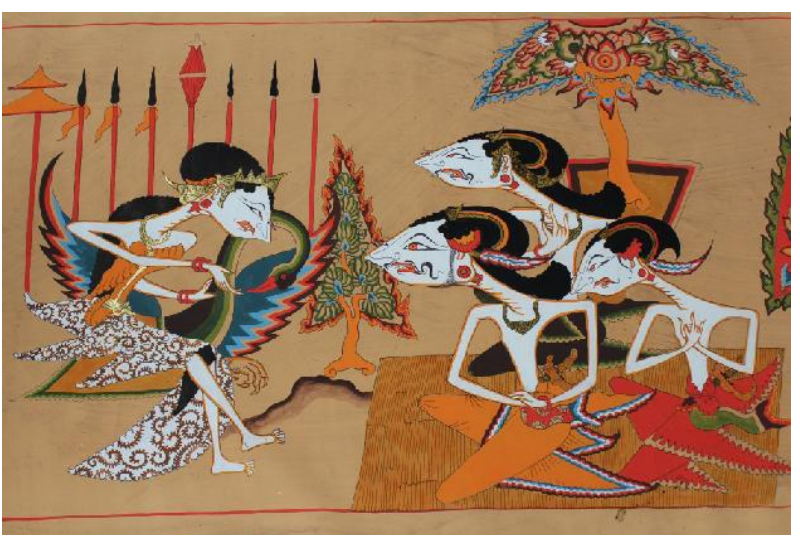

Gambar 11. Sekuen keempat dari gulungan kedua wayang bèbèr karya Mahmudi. (Foto: Elisha, 2013)

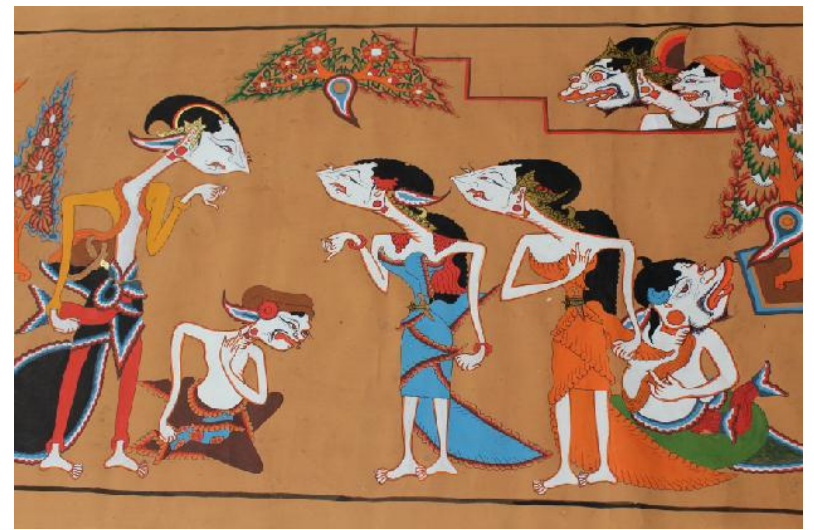

Gambar 13. Sekuen kedua dari gulungan ketiga wayang bèbèr karya Mahmudi. (Foto: Elisha, 2013) 
jatuh pingsan. Tidak berapa lama setelah Ménak Jingga meninggalkan tubuh Damarwulan yang terkapar tak berdaya, datanglah seorang Resi yang bernama Tunggul Manik menolong Damarwulan. Berkat pertolongan Resi Tunggul Manik Damarwulan bisa kembali sehat. Setelah sembuh, Damarwulan segera meminta Wahita dan Puyengan mencuri pusaka Gada Wesi Kuning milik Ménak Jingga.

1. Sekuen keduabelas.

Sekuen kedua belas (gambar 14) melukiskan peperangan Damarwulan melawan Ménak Jingga. Dalam peperangan kali ini Damarwulan dapat mengalahkan Ménak Jingga berkat pusaka Ménak Jingga yang telah dicurinya. Ménak Jingga menjadi tak berdaya dalam peperangan tersebut dan akhirnya mati dengan kepala terpenggal.

\section{Alur Dramatik Wayang Bèbèr Damarwulan}

Wayang Bèbèr Damarwulan ini merupakan transformasi dari lakon pertunjukan kethoprak Sapta Mandala yang berjudul Damarwulan Ménak Jingga. Gambaran lakon tersebut adalah sebagai berikut:

a. Sinopsis.

Adipati Ranggalawé yang merupakan sakaguru Majapahit telah gugur dalam peperangan melawan pemberontakan Adipati Ménak Jingga. Hal itu membuat Ratu Kencana Wungu Raja Majapahit mengalami kebingungan. Ratu Kencana Wungu kesulitan hendak mencari senapati yang kiranya mampu menandingi Adipati Ménak Jingga. Akhirnya Ratu Kencana Wungu memutuskan untuk bersamadi memohon pe-

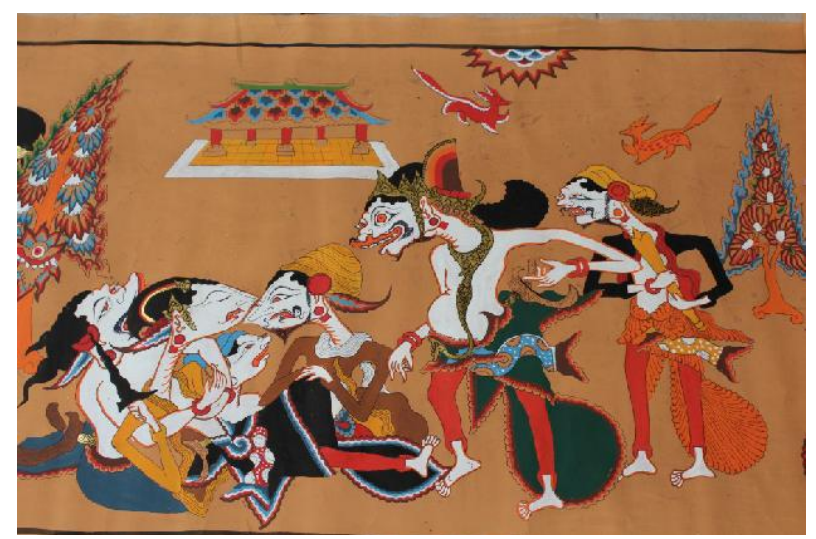

Gambar 13. Sekuen ketiga dari gulungan ketiga wayang bèbèr karya Mahmudi. (Foto: Elisha, 2013) tunjuk dari dewa supaya mendapatkan jalan mengatasi masalah yang melanda Majapahit. Upaya Sang Ratu Kencana Wungu berhasil, ia mendapatkan wangsit bahwa yang dapat menghentikan Adipati Ménak Jingga adalah seorang pemuda dari pertapaan Paluhamba bernama Damarwulan. Pada saat itu Damarwulan menjadi seorang abdi di Kepatihan yang selalu diperlakukan tidak layak oleh Patih Logendèr dan kedua anaknya. Berdasarkan wangsit dewa yang diterima Ratu Kencana Wungu Damarwulanpun segera diangkat menjadi senapati. Ia berhasil mengalahkan Ménak Jingga kemudian diangkat menjadi Raja Majapahit serta memperistri Ratu Kencana Wungu.

b. Tema.

Tema dalam Wayang Bèbèr Damarwulan ini tidak berbeda dengan Damarwulan Ménak Jingga versi kethoprak Sapta Mandala yaitu kesuksesan seorang pemuda yang memiliki karakter tulus, ulet, dan patuh. Sosok yang demikianlah yang menjadi manusia pilihan dewa sehingga mampu meredam sebuah konflik yang besar dan menjadi seorang raja (sukses).

c. Penokohan.

Tokoh-tokoh dalam Wayang Bèbèr Damarwulan terdiri dari beberapa karakter di antaranya: (1) Damarwulan, tokoh Damarwulan ini adalah tokoh protagonis. Karakter yang dimiliki oleh Damarwulan adalah tulus, sabar, dan ulet. (2) Ménak Jingga, tokoh Ménak Jingga adalah tokoh antagonis. Karakter yang dimiliki oleh Ménak Jingga adalah ambisius dan egois. (3) Ratu Kencana Wungu, tokoh Ratu Kencana Wungu adalah sosok yang berwibawa, anggun, dan memiliki karakter bijaksana. (4) Patih Logendèr,

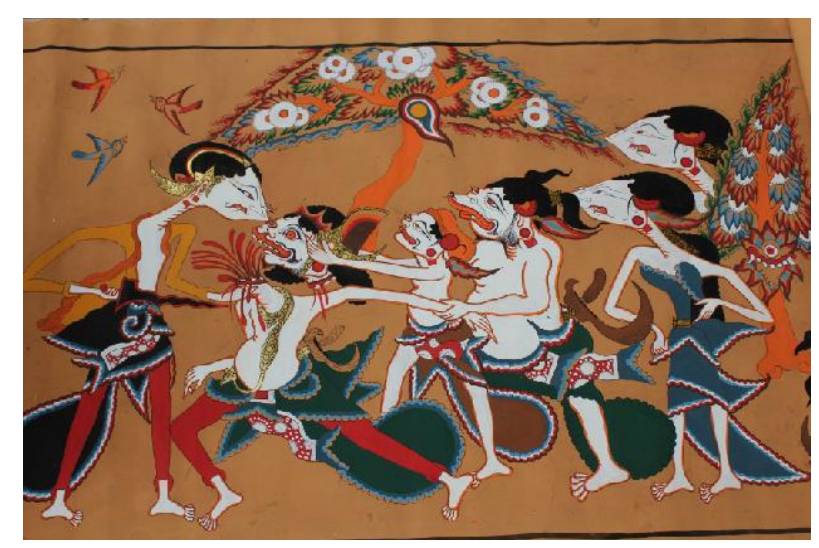

Gambar 14. Sekuen keempat dari gulungan ketiga wayang bèbèr karya Mahmudi. (Foto: Elisha, 2013) 
tokoh Patih Logendèr memiliki karakter yang ambisius, angkuh, dan pilih kasih meskipun dia berada di pihak Majapahit.Tokoh ini tergolong tokoh tritagonis. (5) Anjasmara, tokoh Anjasmara adalah putri Logendèr. Karakter yang dimiliki oleh Anjasmara adalah baik hati, tegas, dan centil. (6) Ménak Koncar, tokoh Ménak Koncar mempuyai karakter yang bijaksana, sopan, dan tegas. (7) Layang Séta, tokoh Layang Séta mempunyai karakter sombong, angkuh, dan licik. (8) Layang Kumitir, tokoh Layang Kumitir mempunyai karakter sombong, angkuh, dan licik. (9) Sabda Palon, tokoh Sabda Palon memiliki karakter humor. (10) Naya Génggong, tokoh Naya Génggong memiliki karakter humor. (11) Angkat Buta adalah tokoh di pihak Ménak Jingga yang memiliki karakter bodoh. (12) Ongkot Buta, sama dengan Angkat Buta, Ongkot Buta adalah tokoh di pihak Ménak Jingga yang memiliki karakter bodoh. (13) Dayun, tokoh Dayun dari pihak Ménak Jingga yang memiliki karakter humor. (14) Wahita, tokoh Wahita memiliki karakter baik hati. (15) Puyengan, tokoh Puyengan memiliki karakter polos. (16) Déwagung Wali Krama, tokoh Déwagung Wali Krama sebagai tokoh sampingan. (17) Emban, tokoh Emban sebagai tokoh sampingan. (18) Prajurit, tokoh Prajurit sebagai tokoh sampingan.

d. Alur (plot).

Alur dalam lakon ini jika dilihat dari segi kualitasnya termasuk jenis alur erat (rapat), jalinan peristiwa di dalamnya sangat padu, jika salah satu kejadian atau tindakan dihilangkan maka akan menggangu cerita (Satoto, 1985: 19). Lakon Damarwulan ini dari adegan satu ke adegan yang lain memiliki hubungan linier. Peristiwa yang terjadi semakin menanjak menuju klimaks yang ditandai oleh kematian Ménak Jingga. Bila digambarkan dalam bentuk diagram tangga dramatik dari sekuen satu sampai dua belas lebih kurang seperti tampak pada gambar 15 .

e. Konflik.

Seperti yang disampaikan di atas, bahwasanya Wayang Bèbèr Damarwulan ini merupakan alur yang erat jalinan konfliknya. Pergerakan alur dramatik dari sekuen satu sampai dengan dua belas semakin naik menuju klimaks. Berikut akan dipaparkan tentang konflik yang terjadi dalam Wayang Bèbèr Damarwulan dari sekuen satu ke sekuen-sekuen selanjutnya. Pada sekuen pertama mulai muncul permasalahan. Ratu Kencana Wungu gelisah mencari senapati untuk mengalahkan Adipati Ménak Jingga. Sebelum menemukan sebuah keputusan tibatiba datanglah utusan dari pihak Adipati Ménak Jingga melamar Ratu Kencana Wungu sehingga suasana bertambah ricuh. Pada sekuen kedua permasalahan berkelanjutan ketika duta dari Adipati Ménak Jingga bertengkar dengan Layang Séta dan Layang Kumitir dari pihak Majapahit. Pada sekuen ketiga tidak terjadi konflik yang serius. Kedatangan Damarwulan di Kepatihan Majapahit untuk mengabdi diterima namun hanya sebagai penjaga régol. Permasalahan terus berlanjut hingga sekuen keempat yaitu ketika Damarwulan beserta rombongan menjaga régol. Terjadilah pertengkaran dengan Layang Séta dan Layang Kumitir. Masalah muncul karena karakter dari Layang Séta dan Layang Kumitir yang sombong. Konflik semakin memanas di sekuen lima yang ditandai dengan terjadinya pertikaian fisik antara Damarwulan dengan Layang Séta dan Layang Kumitir. Perseteruan tersebut dilerai oleh Patih Logendèr. Damarwulan dianggap bersalah. Patih Logendèr mengganti pekerjaan Damarwulan menjadi pekathik (perawat kuda). Konflik bertambah memuncak di sekuen keenam yaitu ketika Damarwulan bekerja di kandang kuda. Ia beserta rombongan selalu diperlakukan tidak baik oleh Layang Séta dan Layang Kumitir. Konflik bertambah memuncak tatkala suatu hari Damarwulan dan Anjasmara putri sulung

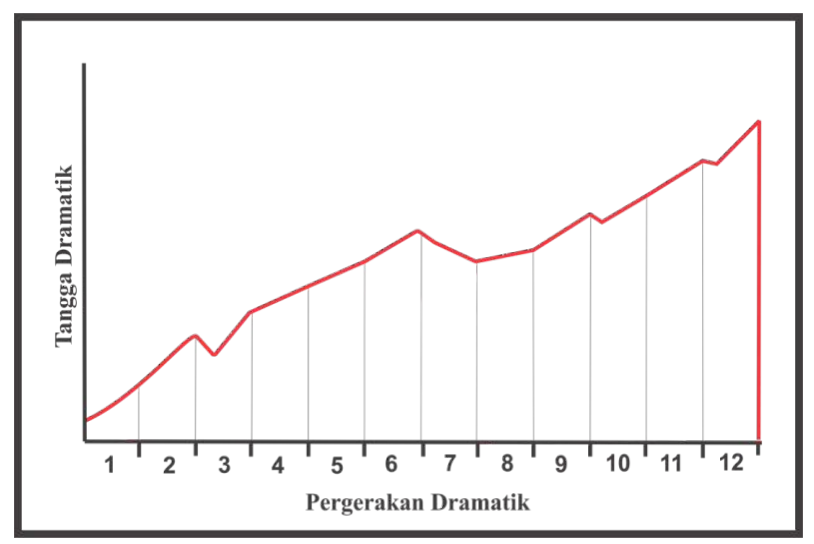

Gambar 15. Diagram tangga dramatik Wayang Bèbèr Damarwulan. (Foto: Elisha, 2013) 
Patih Logendèr ketahuan sedang memadu kasih. Pada sekuen ketujuh ini konflik agak mereda karena berganti adegan (jejeran), yaitu di Kadipaten Blambangan. Dalam adegan ini hanya menggambarkan perasan Ménak Jingga yang saat itu sedang dimabuk cinta. Konflik yang terjadi adalah kemarahan Ménak Jingga terhadap kedua dutanya. Sekuen kedelapan juga masih datar walaupun sempat agak naik turun sedikit karena perdebatan Patih Logendèr. Diceritakan dalam sekuen ini Damarwulan terpilih menjadi senapati Majapahit atas petunjuk dari dewa melalui Ratu Kencana Wungu dalam semedinya. Dalam sekuen kesembilan ini mulai muncul lagi konflik yaitu ketika Damarwulan berpamitan dengan Anjasmara istrinya. Damarwulan tidak diizinkan pergi sehingga Damarwulan harus menggunakan tipu daya. Konflik yang terjadi dalam sekuen kesepuluh terjadi ketika Damarwulan sampai di Blambangan. Ia bertemu dengan dua putri tawanan Ménak Jingga. Damarwulan mencoba menyelamatkan kedua putri tersebut namun ketahuan Ménak Jingga. Akhirnya terjadi perang di antara mereka. Konflik dalam sekuen kesebelas merupakan kelanjutan dari sekuen sebelumnya. Dalam perang tersebut Damarwulan mengalami kekalahan, cidera dan hampir mati. Atas pertolongan dari seorang resi bernama Tunggul Manik, Damarwulan bisa sembuh. Selain itu Wahita dan Puyengan pun bersedia membantu Damarwulan dengan mencuri pusaka milik Ménak Jingga. Sekuen kedua belas ini merupakan klimaksnya. Damarwulan kembali bertarung dengan Ménak Jingga dan akhirnya bisa mengalahkannya dengan cara memenggal dan membawa pulang kepalanya ke Majapahit.

\section{Pemanggungan Wayang Bèbèr Damarwulan}

Pemanggungan Wayang Bèbèr Damarwulan ini mengacu pada wayang bèbèr Wonosari, walaupun ada beberapa unsur dalam wayang tersebut yang digarap sesuai dengan ide perancang. Unsur-unsur yang digarap dipaparkan berikut ini.

a. Tata panggung.

Tata panggung Wayang Bèbèr Damarwulan ini mengacu pada pertunjukan wayang bèbèr
Wonosari, yakni: Dalang menggunakan tuding untuk menunjuk-nunjuk gambar yang sedang diceritakan. Posisi dalang di depan bentangan wayang. Wiyaga (penabuh iringan gamelan) juga di depan wayang bèbèr, di belakang dalang. Agar penonton tidak terhalang oleh pengiring (wiyaga) maupun dalang, maka tempat untuk membentangkan wayang bèbèr dibuat lebih tinggi, yaitu meminjam panggungan wayang golek.

b. Tata lampu.

Fungsi pencahayaan dalam pertunjukan Wayang Bèbèr Damarwulan ini tidak hanya sebagai penerang saja, melainkan juga sebagai unsur pembangun suasana. Kapasitas cahaya, warna, dan fokusnya diatur sesuai dengan suasana pada alur cerita. Agar penonton terfokus pada wayang bèbèr dan performa dalang, maka pencahayaan lebih diarahkan pada bentangan wayang bèbèr sedangkan obyek-obyek yang lain lebih redup.

c. Iringan.

Tidak terlepas dari kekhasan wayang bèbèr yang sederhana, pertunjukan Wayang Bèbèr Damarwulan ini pun menggunakan gamelan laras Sléndro yang sederhana, terdiri dari kendhang, gendèr, rebab, kenong, gong kempul, siter, gambang, slenthem, dan suling. Meski sederhana, tetapi tetap digarap, tidak hanya sebatas ilustrasi melainkan juga sebagai pendukung suasana sehingga berbeda dengan wayang bèbèr yang sudah ada agar lebih menarik.

d. Penarasian.

Oleh karena Wayang Bèbèr Damarwulan ini merupakan perpaduan antara kethoprak dan wayang bèbèr, maka dalam menarasikannya tetap menggunakan idiom-idiom kethoprak dengan bahasa sederhana dan realistis. Bentuk penarasian wayang bèbèr ini terbagi menjadi tiga bentuk yaitu: (1) Dialog menggunakan bahasa Jawa krama (bahasa Jawa halus), krama madya (bahasa Jawa antara ragam halus dan kasar), ngoko (bahasa Jawa kasar), krama désa (bahasa Jawa halus yang biasa digunakan oleh masyarakat yang tinggal jauh dari kraton), kadang-kadang terselip juga bahasa Jawa kuna, Arab, dan Inggris (Sudyarsana, 1989: 20). Kandha dan janturan untuk menjelaskan tentang apa yang terjadi di dalam gambar wayang bèbèr dan menerangkan 
tentang fenomena dalam cerita. Lagu (tembang) untuk menambah nilai artistik dan estetika dalam pertunjukan.

\section{Penutup}

Pembuatan karya Wayang Bèbèr Damarwulan ini merupakan sebuah interpretasi ulang atas wayang bèbèr Pacitan dan Wonosari dalam rangka revitalisasi wayang bèbèr. Karya ini merupakan hasil alih wahana dari pertunjukan kethoprak lakon Damarwulan Ménak Jingga ke dalam pertunjukan Wayang Bèbèr Damarwulan. Karya ini dibuat dengan menggunakan teori alih wahana dan sistem Ruang Waktu Datar. Revitalisasi wayang bèbèr ini dimaksud sebagai upaya agar wayang bèbèr menjadi lebih menarik dan diminati masyarakat.

Upaya revitalisasi ini tentunya tidak mungkin mampu dilakukan sendirian, melainkan perlu dukungan dan kerjasama dari masyarakat serta berbagai pihak yang bertanggung jawab, seperti para seniman, institusi yang bergerak dalam bidang seni budaya dan pariwisata, LSM seni, dan lain sebagainya. Melalui karya ini, diharapkan dapat menginspirasi dan memotivasi masyarakat untuk peduli terhadap seni budaya khususnya wayang bèbèr yang kini keberadaannya memprihatinkan agar bisa kembali eksis sehingga wayang bèbèr dapat lestari dan terus berkembang.

\section{Kepustakaan}

\section{a. Acuan}

Brandon, James R. 2003. Jejak-jejak Seni
Pertunjukan di Asia Tenggara diindonesiakan oleh R.M. Soedarsono. Bandung: PT UPI Press.

Damono, Sapardi Djoko. 2012. Alih Wahana. Jakarta: Editum.

Dirjen Kebudayaan.1984. Album Wayang Bèbèr Pacitan Dan Yogyakarta. Jakarta: Proyek Media Kebudayaan

Holt, Claire. 2000. Melacak Jejak Perkembangan Seni Di Indonesia. Bandung: Artiline.

Sudyarsana, Handung Kus. 1989. Kethoprak. Yogyakarta: Penerbit Kanisius.

Satoto, Soediro. 1983. Wayang Kulit Purwa Makna Dan Struktur Dramatiknya. Yogyakarta: Proyek Penelitian dan Pengkajian Kebudayaan Nusantara Direktorat Jendral Kebudayaan Departemen Pendidikan dan Kebudayaan.

Sayid, R. M. 1980. Sejarah Wayang Bèbèr. Solo: Reksa Pustaka.

Suharyono, Subagya. 2005. Wayang Bèbèr Wonosari. Wonogiri: Bina Cita Pustaka.

Tabrani, Primadi. 2005. Bahasa Rupa. Yogyakarta: Kelir.

\section{b. Audio-Visual}

Kethoprak Sapta Mandala. tt. Lakon Damarwulan Minakjinggo. (kaset) Produksi PT. Bintang Fajar Record (NPWP/TH: 01.210.689.4$509.00072011)$

\section{c. Narasumber}

Ny Rubiyem. Umur 67 tahun. Pemilik Wayang Bèbèr. Alamat: Gelaran II, Karangmojo, Gunung Kidul Yogyakarta. 